\title{
Study on the Selection of Comminution Circuits for a Magnetite Ore in Eastern Hebei, China
}

\author{
Guangquan Liang ${ }^{1,2, *}$, Dezhou Wei ${ }^{1, *}$, Xinyang $\mathrm{Xu}^{1}$, Xiwen $\mathrm{Xia}^{2}$ and $\mathrm{Yubiao} \mathrm{Li}^{3, *}$ \\ 1 College of Resources and Civil Engineering, Northeastern University, Shenyang 110819, China; \\ xuxinyang@mail.neu.edu.cn \\ 2 Hebei Iron \& Steel Group Mining Co. Ltd., Tangshan 063000, China; xxw_619@163.com \\ 3 School of Resources and Environmental Engineering, Wuhan University of Technology, \\ Wuhan 430070, China \\ * Correspondence: liangguangquan1984@126.com (G.L.); dzwei@mail.neu.edu.cn (D.W.); \\ Yubiao.Li@whut.edu.cn (Y.L.)
}

Academic Editors: Thomas Mütze and Massimiliano Zanin

Received: 18 December 2015; Accepted: 20 April 2016; Published: 26 April 2016

\begin{abstract}
Standard drop weight, SMC, and Bond ball work index tests have been conducted to investigate the comminution circuit of a magnetite ore located in Eastern Hebei, China. In addition, simulations based on JKSimMet and Morrell models have been performed to compare the specific energy consumption of various comminution circuits. According to the desired capacity and the ore communition characteristics observed, a simulation was conducted to determine the size and driving power of the grinding mills. The SMC and Bond ball work index experiments as well as the Morrell model indicated that the order of the specific energy consumption of comminution was "Jaw crusher + HPGR mill + ball mill" < "Jaw crusher + ball mill" < "SAG mill + ball mill".
\end{abstract}

Keywords: standard drop weigh test; SMC test; Bond ball work index test; JKSimMet; Morrell

\section{Introduction}

Grinding, as aimed at generating fine particles to achieve libration or specific surface area, is a critical unit and the highest energy consumption process in a typical mineral processing plant, accounting for $50 \% \sim 60 \%$ of the total electrical energy expenditure. Many attempts have been conducted to improve grinding efficiency both in the development of related machines and designation of the grinding systems to reduce energy consumption, with the later being readily achieved by the simulation pathway which is an extremly useful tool and has been widely applied in the mineral industry [1]. The development of mathematical modelling and computer simulation commenced several decades ago and Bond [2] initially introduced the work index concept (Equation (1)) for an energy-based model for grinding mills. To date, simulation strategy is still an active research field in mineral processing and a few commercial steady-state simulators such as USIM PAC 2 [3], BMCS [4], COMSIM [5], and JKSimMet ${ }^{\mathrm{TM}}[6,7]$ have been applied by the industrial users.

$$
W=10 \times W_{i}\left[\frac{1}{\sqrt{P_{80}}}-\frac{1}{\sqrt{F_{80}}}\right]
$$

where $W(\mathrm{kWh} / \mathrm{t})$ is the specific energy for grinding while $W_{i}$ is the work index in $\mathrm{kWh} / \mathrm{t}, P_{80}$ and $F_{80}$ are the $d_{80}$ size of circuit product and feed, respectively.

Australian research groups such as the Julius Kruttschnitt Mineral Research Centre (JKMRC) have, for more than 50 years, been leaders in the development of comminution models and their application in simulation. JKSimMet [7-11], as one of the most widespread simulation softwares used over the world, has been normally used for cost-effective design prior to the construction of mineral processing 
plants or modification of the existing circuits to improve performance or adapt to the changed feeding conditions [9]. The specific energy of tumbling mills such as autogenous (AG), semi-autogenous (SAG), and ball mills have been successfully predicted by the Morrell model [12-15]. In addition, the high pressure grinding rolls (HPGR) has also been developed recently due to its high energy efficiency in comminuting minerals and is regarded as an alternative to less efficient processes such as SAG and ball mills that presently dominate the mineral industry [15]. Therefore, it is necessary to predict the energy consumption of these circuits prior to the implementation of planned plants.

In order to select a suitable circuit for a magnetite ore plant in Hebei province, China, three different comminution circuits (i.e., jaw crusher + HPGR mill + ball mill, jaw crusher + ball mill, and SAG mill + ball mill) and their overall specific energies were compared based on simulations from JKSimMet and Morrell models. In addition, the modelling work presented herein will also assist in optimizing the comminution flowsheet before designing the scaled up plant, saving a huge amount of investment.

\section{Methodology}

\subsection{Standard Drop Weight Test}

The JK standard drop weight device comprises a steel drop weight that can be raised by a winch to a known height. A pneumatic switch releases the drop weight which then falls under gravity and impacts on a rock particle that is positioned on a steel anvil. The device is enclosed in Perspex shielding and incorporates a variety of features to ensure operator safety. By varying the mass of the drop weight and the height where the drop weight is released, a very wide range of energy inputs can be generated. After release, the drop weight falls freely and impacts the target rock particle. The particle is then comminuted and the drop weight is brought to rest at a distance above the anvil approximately equal to the largest product particle. The difference in distance between the initial starting point and the final resting place of the drop weight is used to calculate the energy that is consumed in breaking the rock particle [16].

Five size fractions of particles, i.e., 63-53, 45-37.5, 31.5-26.5, 22.4-19, and 16-13.2 mm, were tested under three specific comminution energies ranging from 0.1 to $2.5 \mathrm{kWh} / \mathrm{t}$ [17]. To represent the impact breakage mechanism in the model, 15 pairs of $t_{10} / E c s$ data from the JK standard drop weight test are subjected to non-linear least squares techniques to fit Equation (2) that describes the relationship between breakage and impact energy:

$$
t_{10}=\mathrm{A}\left(1-\mathrm{e}^{-\mathrm{b} \cdot E c s}\right)
$$

where $t_{10}$ represents the percentage of the comminuted particles with a size less than $1 / 10$ of the initial mean particle size, while $\mathrm{A}$ and $\mathrm{b}$ are the ore impact breakage parameters determined by the drop weight test [16]. The $t_{10}$ can be thought of as a "fineness index" with larger values of $t_{10}$ indicating a finer product size distribution. As $\mathrm{A}$ and $\mathrm{b}$ are independent and cannot be used individually for comparison purpose among ores, JKTech recommends the values of $\mathrm{A} \times \mathrm{b}$ and $t_{10}$ when specific energy consumption is set at $1 \mathrm{kWh} / \mathrm{t}$ for comparison. A lower $\mathrm{A} \times \mathrm{b}$ value indicates a higher strength of the rock.

In addition, 30 grains of ore particles ranging from 31.5 to $26.5 \mathrm{~mm}$ are randomly selected for further density analysis, i.e., weighing the particles in air and water, respectively and then calculating their densities. This process is considered as a very important step during the standard drop weight experiment. It should be noted that the density herein is the grain density, not the density of the solid phase. This means that the internal voids of the particle are also considered in the calculation of grain density. Therefore, the grain density is more significant in evaluating the AG/SAG characterization of ores. Generally, the grain density varies, even for large size ore in the drop weight test, due mainly to the different ore composition from particle to particle. Thus, particles with high grain density and impact comminution resistance should be given considerable attention in the AG/SAG process as these particles accumulate in the SAG/AG mill and can result in increased energy consumption. 


\subsection{Abrasion Test}

Abrasion tests were conducted in a tumbling mill $(\Phi 305 \mathrm{~mm} \times 305 \mathrm{~mm})$ using $3 \mathrm{~kg}$ samples (53-38 $\mathrm{mm}$ ) with four lifter bars $(6 \mathrm{~mm})$. In the absence of grinding media, the mill was operated with a rotation speed of $53 \mathrm{rpm}$ ( $70 \%$ of the desired speed) for $10 \mathrm{~min}$. Then $t^{\prime}{ }_{10}$ can be calculated based on the sieved products. The grinding resistant characteristic $t_{a}$ can then be expressed as one tenth of $t^{\prime}{ }_{10}$, i.e., as given in Equation (3):

$$
t_{a}=t^{\prime}{ }_{10} / 10
$$

\subsection{SMC Test}

The investigation of the impact comminution of particles in the SMC test was similar to the drop weight experiment. However, SMC tests were carried out at five different specific energy consumptions and only $t_{10}$ values were required for sieving analysis. In this study, 100 particles ranging from -22.4 to $19 \mathrm{~mm}$ were selected from the crushed products, which were divided into five groups (i.e., 20 particles per group) for SMC tests. Subsequently, impact comminution tests were conducted for single particles in each group and $t_{10}$ values were collected.

The drop weight index $\left(D W_{i}\right.$, unit: $\left.\mathrm{kWh} / \mathrm{m}^{3}\right)$, as an indicator of impact comminution resistance for ores, can be used to estimate $\mathrm{A}, \mathrm{b}$, and $t_{a}$. A greater $D W_{i}$ indicates a greater comminution resistance capacity of the mineral. In addition, three parameters such as $M_{i a}$ (coarse ore work index), $M_{i c}$ (crushing ore work index) and $M_{i h}$ (HPGR ore work index) can be obtained from the SMC tests [15]. These parameters can be further used to evaluate specific energy consumption in the Morrell model.

\subsection{Bond Ball Work Index Test}

A grinding mill ( $\Phi 305 \mathrm{~mm} \times 305 \mathrm{~mm})$ was used for the Bond ball mill work index test [18-21]. This ball mill was filled with 285 steel balls (total weight of $20.125 \mathrm{~kg}$ ) at an operation speed of $70 \mathrm{rpm}$. The feed sample was prepared via crushing and sieving, giving rise to a size smaller than $3.35 \mathrm{~mm}$. A particle size of $P_{100}=150 \mu \mathrm{m}$ in closed circuit was applied. In addition, $F_{80}$, $P_{80}$ and $G_{b p}(\mathrm{~g} / \mathrm{r})$ were obtained during this test, while $W_{i b}$ and $M_{i b}$ can be calculated according to Morrell [15]. It should be noted that the mean cycling charge should be within $250 \% \pm 5 \%$ and $\left(G_{b p(\max )}-G_{b p(\min )}\right) / G_{b p(\text { mean })} \leqslant 3 \%$.

\subsection{Specific Energy Determination}

The total specific energy $\left(W_{T}\right)$ to reduce ore size from the crusher product to the final grinding product is given by Equation (4) [15]:

$$
W_{T}=W_{a}+W_{b}+W_{c}+W_{h}+W_{s}
$$

where:

$W_{a}=$ specific energy to grind coarser particles in the tumbling mill;

$W_{b}=$ specific energy to grind finer particles in the tumbling mill;

$W_{c}=$ specific energy for conventional crushing;

$W_{h}=$ specific energy for HPGR;

$W_{s}=$ specific energy correctioin for size distribution.

The related definition of the above specific energy is referred byMorrell [15] and comparison of the comminution circuits is based on the $W_{T}$ calculation (Equation (4)).

\subsection{Simulators and Data Analysis}

The data obtained from the standard drop weight and the SMC tests were further processed using the JKSimMet and Morrell models mentioned in Section 1. The non-linear fitting of the data was conducted using Matlab. 


\section{Results and Discussion}

\subsection{Standard Drop Weight Test}

Figure 1 shows the $t_{10}$ values at various specific energy consumptions. The regression results indicate that the values of $\mathrm{A}$ and $\mathrm{b}$ are 66.1 and 0.81 , respectively, so $\mathrm{A} \times \mathrm{b}$ is 53.5 . From this fitting, it can be seen that the $t_{10}$ value is $36.7 \%$ when $E_{\mathcal{C S}}$ is $1 \mathrm{kWh} / \mathrm{t}$.

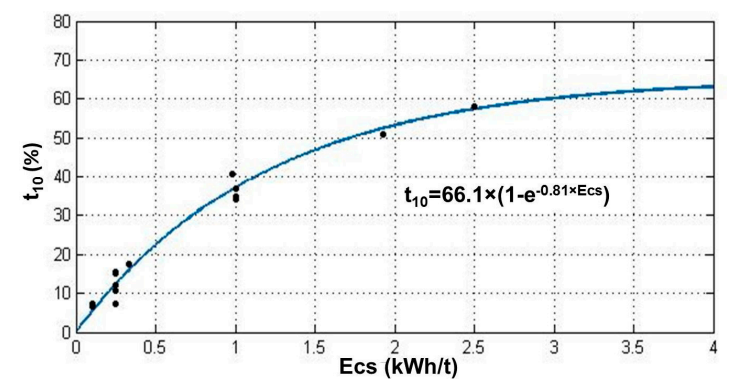

Figure 1. Fitted $t_{10}-E_{\mathcal{~ S S}}$ curve of the magnetite ore.

Further comparative comminution tests between the real ore and the JKTech modelling are shown in Table 1. Generally, an $\mathrm{A} \times \mathrm{b}$ value smaller than 20 indicates a hard ore while a value greater than 250 suggests a soft ore. When the specific energy consumption is set at $1 \mathrm{kWh} / \mathrm{t}$, a $t_{10}$ value less than $15 \%$ or greater than $75 \%$ indicates hard or soft ores, respectively [17]. Therefore, an $\mathrm{A} \times \mathrm{b}$ value of 53.3 obtained for this magnetite ore indicates that the impact comminution resistance is greater than $60.8 \%$ (i.e., 2806) of tested ores (i.e., 4616) in the database, while a $t_{10}$ value of $36.7 \%$ is greater than 3053 $(66.1 \%)$ the ores tested.

Table 1. Comparison between the Eastern Hebei magnetite ore and JKTech ore characteristic database.

\begin{tabular}{|c|c|c|c|c|c|c|c|c|c|}
\hline \multirow{2}{*}{ Parameter } & \multicolumn{3}{|c|}{$\mathbf{A} \times \mathbf{b}$} & \multicolumn{3}{|c|}{$t_{10}$ When $E_{c s}=1 \mathrm{kWh} / \mathrm{t}$} & \multicolumn{3}{|c|}{$t_{a}$} \\
\hline & Value & Rank & $\%$ & Value & Rank & $\%$ & Value & Rank & $\%$ \\
\hline Database minimum & 12.9 & 1 & 0 & 7.9 & 1 & 0 & 0 & 1 & 0 \\
\hline Database median & 45.8 & 2308 & 50 & 32.1 & 2308 & 50 & 0.5 & 2337 & 50 \\
\hline Database average & 63.6 & 3293 & 71.3 & 34.6 & 2719 & 58.9 & 0.6 & 3228 & 69.5 \\
\hline Database maximum & 809.6 & 4616 & 100 & 93.6 & 4616 & 100 & 6.9 & 4644 & 100 \\
\hline Magnetite test & 53.5 & 2806 & 60.8 & 36.7 & 3053 & 66.1 & 0.28 & 834 & 18 \\
\hline
\end{tabular}

Figure 2 shows the density tests of the 30 grains ranging from 31.5 to $26.5 \mathrm{~mm}$. The particle number of each density range is shown in Figure 2a where no dual-peak was observed, indicating that no aggregation of particles in the grinding mill was expected. Figure $2 b$ shows that the maximum and minimum densities of these 30 particles were 3.75 and $2.71 \mathrm{t} / \mathrm{m}^{3}$, respectively, with average and median values of 3.32 and $3.38 \mathrm{t} / \mathrm{m}^{3}$, respectively.
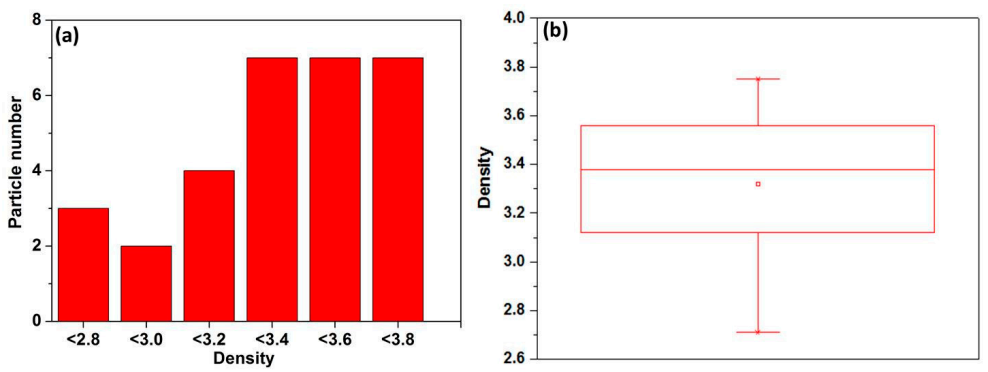

Figure 2. Density distribution of 30 particles ranging from 31.5 to $26.5 \mathrm{~mm}$. (a) Particle number as a function of density; (b) Statistic analysis of the density. 


\subsection{Abrasion Test}

Table 1 indicates a $t_{a}$ value of 0.28 which is located at number 834 out of 4644 , indicating that only $18.0 \%$ of the tested ores in the JKTech database are relatively readily ground than the Eastern Hebei magnetite ore, further suggesting that this ore is difficult to comminute. Therefore, it can be used in the SAG mill circuit.

\subsection{SMC Test}

Figure 3 shows the fitted SMC test results and the A and b values were fitted as 79.1 and 0.66 $(\mathrm{A} \times \mathrm{b}=52.2)$, with a $t_{10}$ value of $38.2 \%$ when $E_{c s}$ was $1 \mathrm{kWh} / \mathrm{t}$. $t_{a}$ was calculated as $0.40 \%$ for the ore size located in this range. Within the SMC database including 4616 minerals, the A $\times \mathrm{b}$ value of 52.2 ranks at $59 \%$ while the $t_{10}$ value of $38.2 \%$ ranks at $70.6 \%$. Compared to the drop weight test, there is no significant difference in the $\mathrm{A} \times \mathrm{b}$ values but the $t_{a}$ obtained from the SMC test is apparently greater.

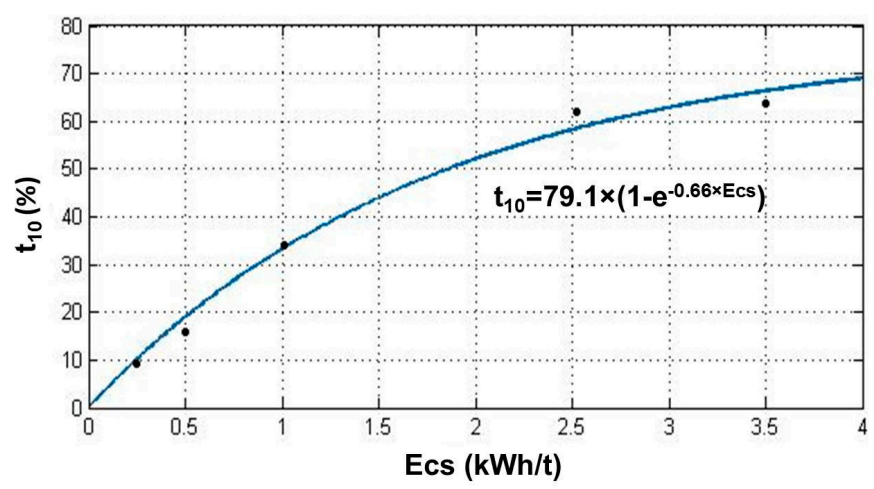

Figure 3. Fitted $t_{10}-E_{c S}$ curve for the SMC tests.

Table 2 shows further results derived from the SMC tests. The $D W_{i}$ value of $6.49 \mathrm{kWh} / \mathrm{m}^{3}$ obtained for the Eastern Hebei magnetite ore indicates that $61 \%$ of the ores tested in the SMCT database are easier to comminute than this ore. In addition, the $M_{i a}, M_{i h}$, and $M_{i c}$ values of this ore were calculated as $15.1,11.1$, and $5.7 \mathrm{kWh} / \mathrm{t}$, respectively, greater than approximately $40 \%, 45 \%$, and $42 \%$ of the ores tested in the database.

Table 2. Material parameters of the SMC tests.

\begin{tabular}{cccccc}
\hline Parameter & $D W_{i}\left(\mathbf{k W h} / \mathbf{m}^{3}\right)$ & $D W_{i}(\%)$ & $M_{i a}(\mathbf{k W h} / \mathbf{t})$ & $M_{i h}(\mathbf{k W h} / \mathbf{t})$ & $M_{i c}(\mathbf{k W h} / \mathbf{t})$ \\
\hline Value & 6.49 & 61 & 15.1 & 11.1 & 5.7 \\
\hline
\end{tabular}

\subsection{Bond Ball Work Index Test}

Table 3 shows the experimental parameters for the Bond ball work index test of the Eastern Hebei magnetite ore. An average cycling charge of $246.14 \%$ and a $G_{b p}$ of $2.72 \%$ during the last three cycles were observed, which were within the required error ranges of $250 \% \pm 5 \%$ and $3 \%$, respectively, indicating termination of the test.

Table 4 shows the results of Bond ball work index test where the $F_{80}$ and $P_{80}$ were calculated as 1450 and $119.6 \mu \mathrm{m}$, respectively, with the detailed size distribution being shown in Figure 4. In addition, the $W_{i b}$ and $M_{i b}$ values were calculated to be 10.93 and $12.54 \mathrm{kWt} / \mathrm{t}$, respectively. 
Table 3. Bond ball work index test.

\begin{tabular}{ccccccc}
\hline \multirow{2}{*}{ Cycle } & \multirow{2}{*}{ New Feed (g) } & \multirow{2}{*}{ Speed $(\mathbf{r p m})$} & \multicolumn{3}{c}{ Particle Size $<\mathbf{1 5 0} \boldsymbol{\mu \mathbf { m }} \mathbf{( g )}$} & \multirow{2}{*}{$\boldsymbol{G}_{b p}(\mathbf{g} / \mathbf{r})$} \\
\cline { 3 - 5 } & & & Total & From Feed & New Formed & \\
\hline 1 & 1365.0 & 100 & 583.9 & 414.8 & 169.1 & 1.6910 \\
2 & 583.9 & 126 & 464.5 & 177.4 & 287.1 & 2.2786 \\
3 & 464.5 & 109 & 379.6 & 141.1 & 238.5 & 2.1881 \\
4 & 379.6 & 106 & 406.8 & 115.3 & 291.5 & 2.3135 \\
5 & 406.8 & 115 & 409.0 & 123.6 & 285.4 & 2.4817 \\
6 & 409.0 & 107 & 383.2 & 124.3 & 258.9 & 2.4196 \\
7 & 383.2 & 113 & 397.9 & 116.4 & 281.5 & 2.4912 \\
8 & 397.9 & 108 & 398.1 & 120.9 & 277.2 & 2.5667 \\
9 & 398.1 & 105 & 394.2 & 121.0 & 273.2 & 2.6019 \\
10 & 394.2 & 104 & 390.8 & 119.8 & 271.0 & 2.6058 \\
11 & 390.8 & 104 & 382.5 & 118.8 & 263.7 & 2.5356 \\
\hline
\end{tabular}

Table 4. The results of Bond ball work index test.

\begin{tabular}{cccccc}
\hline Parameter & $G_{b p}(\mathrm{~g} / \mathrm{r})$ & $F_{\mathbf{8 0}}(\mu \mathrm{m})$ & $\boldsymbol{P}_{\mathbf{8 0}}(\mu \mathrm{m})$ & $W_{i b}(\mathbf{k W h} / \mathbf{t})$ & $M_{i b}(\mathbf{k W h} / \mathbf{t})$ \\
\hline Value & 2.5811 & 1450 & 119.6 & 10.93 & 12.54 \\
\hline
\end{tabular}

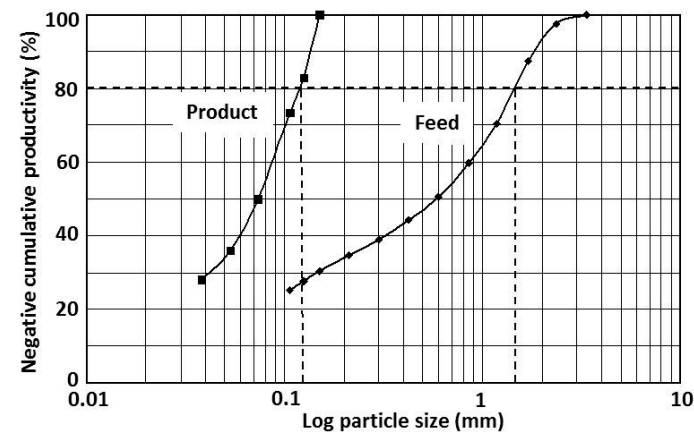

Figure 4. Particle size distribution of Bond ball work index test.

\subsection{Selection of Comminution Circuit Based on Modelling}

\subsubsection{Establishment of SAG-Ball Mill Circuit}

Figure 5 shows the well-established model for a closed-circuit SAG-ball mill using JKSimMet. Apart from the primary parts of the circuit, such as the SAG mill, sieving, ball mill, and hydrocyclone, two water supply modules have been included to adjust the grinding concentration in the SAG mill, i.e., the percentage solids in the feed, and the feed solids for the hydrocyclone, respectively.

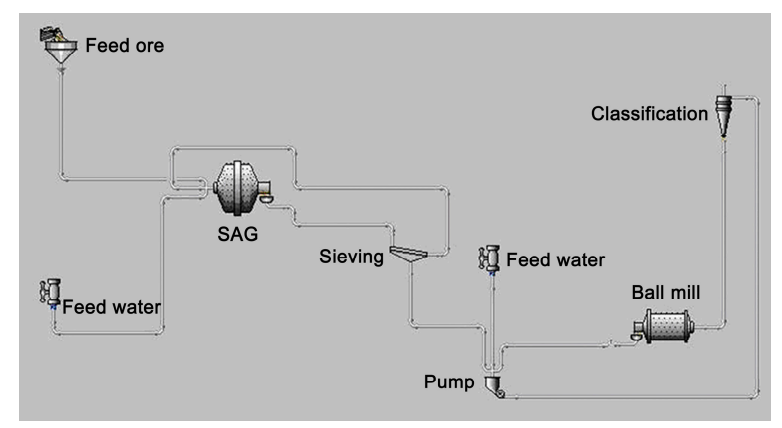

Figure 5. SAG-ball mill circuit for the JKSimMet platform. 
A SAG mill module with a variable speed and a fully mixed ball mill module were selected in the modelling process, with these two modules being able to be enlarged. Standard efficiency curve models were chosen for sieving and cyclone classification. Considering the grinding procedure, the annual handling capacity and the total working time in the grinding and separation sections, the production capacity was calculated as $631.3 \mathrm{t} / \mathrm{h}$. Hence, a feed rate of $635 \mathrm{t} / \mathrm{h}$ was selected.

The ore that was directly obtained from underground was coarsely crushed to $<250 \mathrm{~mm}$, which was then transported to the grinding mill. If the size of the output of the coarse crusher (S) was $150 \mathrm{~mm}$, the $F_{80}$ was calculated to be approximately $111.1 \mathrm{~mm}\left(0.2 \cdot \mathrm{S} \cdot\left(D W_{i}\right)^{0.7}\right)$ and $107.5 \mathrm{~mm}\left(\mathrm{~S}-78.7-28.4 \cdot \ln \left(t_{a}\right)\right)$, respectively, according to the JKSimMet model. Therefore, a $F_{80}$ value of $110 \mathrm{~mm}$ was chosen for closed circuit testing, with the size distribution from this circuit being shown in Figure 6.

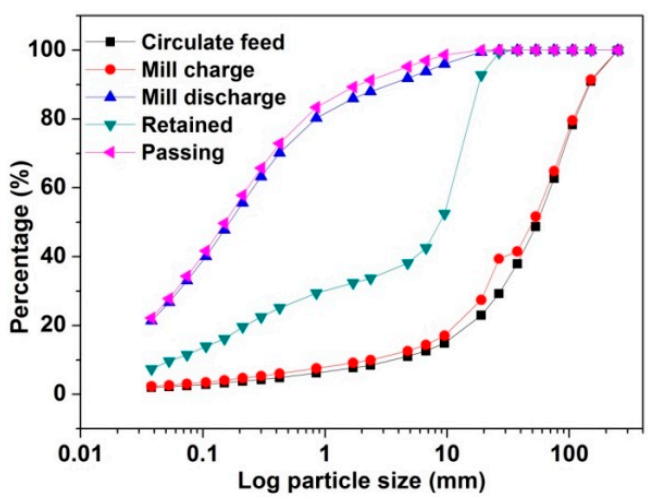

Figure 6. Particle size distribution of SAG-ball mill circuit.

A SAG mill with a diameter of $10.67 \mathrm{~m}$ and a length of $5.33 \mathrm{~m}$ was initially selected for the grinding circuit. It should be noted that the diameter and length chosen are the inner dimensions of the SAG mill. Other parameters such as $74 \%$ of the desired speed, $8 \%$ ball charge, maximum diameter of steel balls of $120 \mathrm{~mm}$, grinding concentration of $75 \%$, grid size of $20 \mathrm{~mm}$, and sieve size of $12 \mathrm{~mm}$ $\left(d_{50 \mathrm{c}}=11 \mathrm{~mm}\right)$ were selected as well. These parameters were initially applied to simulate the steady state process for the SAG circuit. The modelling was conducted based on progressively adjusting parameters until satisfactory results were obtained, e.g., a SAG mill with a mill charge of $25 \%$ solids and a cycling charge less than $25 \%$.

Table 5 shows the progress of adjusting parameters and the results derived from modelling. It was found that the initially selected SAG mills $(\Phi 10.67 \mathrm{~m} \times 5.33 \mathrm{~m}$ and $\Phi 10.36 \mathrm{~m} \times 5.18 \mathrm{~m})$ were too big as the mill charges were $21.81 \%$ and $23.42 \%$, respectively, in the first two modellings. The third SAG mill option with a size of $\Phi 10.06 \mathrm{~m} \times 5.03 \mathrm{~m}$ was quite suitable as the mill charging was $25.25 \%$ with a cycling charge of $6.17 \%$. It should be noted that optimizing the mill charge can be further improved by adjusting other parameters such as increasing the ball charge to $8.5 \%$ to obtain a mill charge of less than $25 \%$ (the fourth simulation shown in Table 5). Therefore, a SAG mill $(\Phi 10.06 \mathrm{~m} \times 5.03 \mathrm{~m})$ with a driving power of $7321 \mathrm{~kW}$ was finally selected, while the related specific energy consumption was calculated as $11.53 \mathrm{kWh} / \mathrm{t}$.

Table 5. Simulation progress for SAG mill modelling.

\begin{tabular}{|c|c|c|c|c|c|c|}
\hline \multirow{2}{*}{$\begin{array}{l}\text { Simulation } \\
\text { Time }\end{array}$} & \multicolumn{2}{|c|}{ Parameters (m) } & \multicolumn{4}{|c|}{ Simulation } \\
\hline & Diameter & Length & $\begin{array}{c}\text { Mill Charge } \\
(\%)\end{array}$ & $\begin{array}{l}\text { Circulating } \\
\text { Load }(t / h)\end{array}$ & $\begin{array}{c}\text { Cycling } \\
\text { Charge (\%) }\end{array}$ & $\begin{array}{l}\text { Mill Power } \\
\text { (kw) }\end{array}$ \\
\hline 1 & 10.67 & 5.33 & 21.81 & 36.18 & 5.70 & 8495 \\
\hline 2 & 10.36 & 5.18 & 23.42 & 37.60 & 5.92 & 7889 \\
\hline 3 & 10.06 & 5.03 & 25.25 & 39.17 & 6.17 & 7321 \\
\hline 4 & 10.06 & 5.03 & 24.47 & 38.67 & 6.09 & 7360 \\
\hline
\end{tabular}


Table 6 shows the modelling results for SAG circuit based on the selected parameters described above, giving a product with a $P_{80}$ value of $0.651 \mathrm{~mm}$ and $34.12 \%$ of final particles smaller than $0.074 \mathrm{~mm}$.

Table 6. Parameters for SAG mill simulation.

\begin{tabular}{cccccc}
\hline Flux & Circulate Load & Mill Charge & Mill Discharge & Retained & Passing \\
\hline Solid flow rate $(\mathrm{t} / \mathrm{h})$ & 635.0 & 674.2 & 674.2 & 39.2 & 635.0 \\
Solid density $\left(\mathrm{t} / \mathrm{m}^{3}\right)$ & 3.30 & 3.30 & 3.30 & 3.30 & 3.30 \\
Liquid flow rate $(\mathrm{t} / \mathrm{h})$ & 0.0 & 224.7 & 224.7 & 4.5 & 220.2 \\
Solid concentration $(\%)$ & 100.0 & 75.0 & 75.0 & 89.71 & 74.25 \\
Pulp density $\left(\mathrm{t} / \mathrm{m}^{3}\right)$ & 3.30 & 2.10 & 2.10 & 2.67 & 2.07 \\
Pulp volume flow rate $\left(\mathrm{m}^{3} / \mathrm{h}\right)$ & 192.4 & 429.0 & 429.0 & 16.4 & 412.7 \\
$-0.074 \mathrm{~mm}(\%)$ & 2.51 & 3.03 & 32.8 & 11.40 & 34.12 \\
$P_{80}(\mathrm{~mm})$ & 110 & 107 & 0.83 & 14.70 & 0.651 \\
\hline
\end{tabular}

\subsubsection{Selection of Ball Mill}

The product from the SAG circuit (Section 3.5.1) was used as the feed to the ball mill circuit. An overflow ball mill with a diameter of $5.03 \mathrm{~m}$ and a length of $8.84 \mathrm{~m}$ was initially selected for the modelling. The operation parameters were set as follows: $73 \%$ of the desired speed, $38 \%$ ball charge, a maximum diameter of $80 \mathrm{~mm}$ for the steel balls, and a solids concentration of $60 \%$ for the hydrocyclone, $d_{50 \mathrm{c}}=0.150 \mathrm{~mm}$. Similar to the SAG circuit simulation, a steady state process was simulated for the ball mill circuit with the requirements of a cycling charge of around $250 \%$ and less than $60 \%$ of the final product with a size of $-0.074 \mathrm{~mm}$, etc. The simulation process and results are shown in Table 7. It is evident that the initial selection of a ball mill size of $\Phi 5.03 \mathrm{~m} \times 8.84 \mathrm{~m}$ produced $61.62 \%-0.074 \mathrm{~mm}$ materials, but the cycling charge was only $240.9 \%$, indicating this size was too big. A slight improvement was observed for the second ball mill $(\Phi 5.03 \mathrm{~m} \times 8.53 \mathrm{~m})$, while the third option $(\Phi 5.03 \mathrm{~m} \times 8.23 \mathrm{~m})$ seemed to meet the requirements. With slight adjustments in hydrocyclone solids concentration and $d_{50 \mathrm{c}}$ in the fourth and fifth simulations, respectively, a mill power of $3767 \mathrm{~kW}$ and a cycling charge of $252.4 \%$ were obtained. The $P_{80}$ of the final product was observed to be $0.137 \mathrm{~mm}$, while the specific energy consumption was calculated as $5.93 \mathrm{kWh} / \mathrm{t}$.

Table 7. The simulation process for ball mill modelling.

\begin{tabular}{|c|c|c|c|c|c|c|c|c|}
\hline \multirow[b]{2}{*}{$\begin{array}{c}\text { Simulation } \\
\text { Time }\end{array}$} & \multicolumn{4}{|c|}{ Parameters } & \multicolumn{4}{|c|}{ Simulation } \\
\hline & $\begin{array}{l}\text { Diameter } \\
\text { (m) }\end{array}$ & $\begin{array}{l}\text { Length } \\
\text { (m) }\end{array}$ & $\begin{array}{c}\text { Hydrocyclone } \\
\text { Solids } \\
\text { Concentration (\%) }\end{array}$ & $\begin{array}{l}d_{50 \mathrm{c}} \\
(\mathrm{mm})\end{array}$ & $\begin{array}{c}-0.074 \mathrm{~mm} \\
(\%)\end{array}$ & $\begin{array}{l}\text { Cycling } \\
\text { Charge } \\
(\%)\end{array}$ & $\begin{array}{c}\text { Product } \\
\text { Concentration } \\
(\%)\end{array}$ & $\begin{array}{l}\text { Mill } \\
\text { Power } \\
(\mathbf{k W})\end{array}$ \\
\hline 1 & 5.03 & 8.84 & 60 & 0.150 & 61.62 & 240.9 & 38.59 & 4045 \\
\hline 2 & 5.03 & 8.53 & 60 & 0.150 & 61.12 & 247.4 & 38.15 & 3905 \\
\hline 3 & 5.03 & 8.23 & 60 & 0.150 & 60.62 & 254.3 & 37.68 & 3769 \\
\hline
\end{tabular}

\subsubsection{Comparison of Comminution Circuits}

The basic data used in the Morrell model were obtained from the SMC and Bond ball work index tests and the specific energy consumptions of the jaw crusher and ball mill circuits were calculated using Equations (5)-(8):

$$
\begin{gathered}
W_{a}=K_{1} M_{i a} 4\left(x_{2} f\left(x_{2}\right)-x_{1} f\left(x_{1}\right)\right) \\
=1.00 \times 15.10 \times 4 \times\left(750^{-\left(0.295+\frac{750}{1000000}\right)}-6500^{-\left(0.295+\frac{6500}{1000000}\right)}\right)=4.25 \mathrm{kWh} / \mathrm{t}
\end{gathered}
$$


where $K_{1}$ is 1.0 for all circuits that do not contain a recycle pebble crusher and 0.95 where circuits do have a pebble crusher, $x_{1}$ is the $P_{80}(\mu \mathrm{m})$ of the product of the last stage of crushing before grinding, $x_{2}$ is $750 \mu \mathrm{m}$, and $M_{i a}$ is the coarse ore work index and provided directly by the SMC Test.

$$
W_{b}=M_{i b} 4\left(x_{3} f\left(x_{3}\right)-x_{2} f\left(x_{2}\right)\right)=12.54 \times 4 \times\left(137^{-\left(0.295+\frac{137}{1000000}\right)}-750^{-\left(0.295+\frac{750}{1000000}\right)}\right)=4.66 \mathrm{kWh} / \mathrm{t}
$$

where $x_{2}$ is $750 \mu \mathrm{m}, x_{3}$ is the $P_{80}(\mu \mathrm{m})$ of final grind, and $M_{i b}$ is provided by data from the standard Bond ball mill work index test.

$$
\begin{gathered}
W_{c}=K_{2} M_{i c} 4\left(x_{2} f\left(x_{2}\right)-x_{1} f\left(x_{1}\right)\right) \\
=1.00 \times 5.70 \times 4 \times\left(6500^{-\left(0.295+\frac{5500}{1000000}\right)}-110000^{-\left(0.295+\frac{110000}{1000000}\right)}\right)=1.41 \mathrm{kWh} / \mathrm{t}
\end{gathered}
$$

where $K_{2}$ is 1.0 for all crushers operating in a closed circuit with a classifying screen. If the crusher is in an open circuit, e.g., a pebble crusher in a AG/SAG circuit, $K_{2}$ takes the value of $1.19, x_{1}$ is the $P_{80}(\mu \mathrm{m})$ of the circuit feed, $x_{2}$ is the $P_{80}(\mu \mathrm{m})$ of the circuit product, and $M_{i c}$ is the coarse ore work index and provided directly by the SMC Test.

$$
\begin{gathered}
W_{s}=K_{3} M_{i a} 4\left(x_{2} f\left(x_{2}\right)-x_{1} f\left(x_{1}\right)\right) \\
=0.19 \times 15.10 \times 4 \times\left(6500^{-\left(0.295+\frac{6550}{1000000}\right)}-110000^{-\left(0.295+\frac{110000}{1000000}\right)}\right)=0.71 \mathrm{kWh} / \mathrm{t}
\end{gathered}
$$

where $K_{3}$ is $0.19, x_{1}$ is the $P_{80}(\mu \mathrm{m})$ of the circuit feed, $x_{2}$ is the $P_{80}(\mu \mathrm{m})$ of the circuit product, and $M_{i a}$ is the coarse ore work index and provided directly by the SMC Test.

The specific energy consumptions of the jaw crusher, HPGR and ball mill circuits were calculated using Equations (9)-(12).

$$
\begin{gathered}
W_{a}=1.00 \times 15.10 \times 4 \times\left(750^{-\left(0.295+\frac{750}{1000000}\right)}-1600^{-\left(0.295+\frac{1600}{1000000}\right)}\right)=1.75 \mathrm{kWh} / \mathrm{t} \\
W_{b}=12.54 \times 4 \times\left(137^{-\left(0.295+\frac{137}{1000000}\right)}-750^{-\left(0.295+\frac{750}{1000000}\right)}\right)=4.66 \mathrm{kWh} / \mathrm{t} \\
W_{c}=1.00 \times 5.70 \times 4 \times\left(12000^{-\left(0.295+\frac{12000}{1000000}\right)}-110000^{-\left(0.295+\frac{110000}{100000}\right)}\right)=1.07 \mathrm{kWh} / \mathrm{t} \\
W_{h}=K_{4} M_{i h} 4\left(x_{2} f\left(x_{2}\right)-x_{1} f\left(x_{1}\right)\right) \\
=1.00 \times 11.10 \times 4 \times\left(1600^{-\left(0.295+\frac{1600}{1000000}\right)}-12000^{-\left(0.295+\frac{12000}{1000000}\right)}\right)=2.49 \mathrm{kWh} / \mathrm{t}
\end{gathered}
$$

$K_{4}$ is 1.0 for all HPGRs operating in closed circuit with a classifying screen. If the HPGR is in open circuit, $K_{4}$ takes the value of $1.19, x_{1}$ is the $P_{80}(\mu \mathrm{m})$ of the circuit feed, $x_{2}$ is the $P_{80}(\mu \mathrm{m})$ of the circuit product, and $M_{i h}$ is the HPGR ore work index and provided directly by the SMC Test.

The specific energy consumptions of the SAG and ball mill circuits were calculated using Equations (13) and (14).

$$
\begin{gathered}
W_{a}=1.00 \times 15.10 \times 4 \times\left(750^{-\left(0.295+\frac{750}{1000000}\right)}-110000^{-\left(0.295+\frac{110000}{1000000}\right)}\right)=7.98 \mathrm{kWh} / \mathrm{t} \\
W_{b}=12.54 \times 4 \times\left(137^{-\left(0.295+\frac{137}{1000000}\right)}-750^{-\left(0.295+\frac{750}{1000000}\right)}\right)=4.66 \mathrm{kWh} / \mathrm{t}
\end{gathered}
$$

All these specific energy consumptions of the three combined circuits are shown in Table 8. 
Table 8. Specific energy consumptions of the three combined circuits.

\begin{tabular}{cccc}
\hline $\boldsymbol{W} \mathbf{( k W h / t )}$ & Crusher + Ball Mill & Crusher +HPGR + Ball Mill & SAG + Ball Mill \\
\hline$W_{a}$ & 4.25 & 1.75 & 7.98 \\
$W_{b}$ & 4.66 & 4.66 & 4.66 \\
$W_{c}$ & 1.41 & 1.07 & - \\
$W_{h}$ & - & 2.49 & - \\
$W_{s}$ & 0.71 & - & - \\
$W_{T}$ & 11.03 & 9.97 & 12.64 \\
\hline
\end{tabular}

According to the calculation shown above, the specific energy consumption of the second pathway, i.e., jaw crusher + HPGR mill + ball mill, was $1 \mathrm{kWh} / \mathrm{t}$ lower than that of the jaw crusher + ball mill option, with the SAG mill + ball mill option being the highest in specific energy consumption.

It should be noted that the specific energy consumption of comminution is the "net energy consumed" in comminuting ores. Some other energies consumed were not considered, e.g., the driving force for the trunnion when using a tumbling mill, the shaft power for the HPGR mill, and the balance between the motor power and no-load power for the jaw crusher. Assuming that the energy loss between the motor and the transmitted power is $6.5 \%$ for the tumbling mill, it is estimated that the "gross energy consumption" related to the motor input power was $13.52 \mathrm{kWh} / \mathrm{t}$, which is relatively lower than the $17.46 \mathrm{kWh} / \mathrm{t}$ estimated by the JKSimMet model.

The specific energy consumption estimated by the Morrell model was only based on several material characteristics, however, the variation in parameters and technical processes were not considered. In addition, the energy saved in the discarding of coarse particles was not taken into account. These factors will be further investigated in future studies.

\section{Conclusions}

1. Parameters characterizing impact comminution resistance, such as $\mathrm{A}=66.1, \mathrm{~b}=0.81$ (thus $\mathrm{A} \times \mathrm{b}=53.5)$ and $t_{a}=0.28$, were obtained from the standard drop weight tests;

2. The SMC tests indicated that $\mathrm{A}=79.1, \mathrm{~b}=0.66$ (thus $\mathrm{A} \times \mathrm{b}=53.5$ ) and $t_{a}=0.40$. In addition, the values of $D W_{i}, M_{i a}, M_{i h}$, and $M_{i c}$ were $6.49 \mathrm{kWh} / \mathrm{m}^{3}, 15.10,11.10$ and $5.70 \mathrm{kWh} / \mathrm{t}$, respectively;

3. The Bond ball work index tests indicated a $W_{i b}$ value of $10.93 \mathrm{kWh} / \mathrm{t}$, while the Morrell model indicated a $M_{i b}$ value of $12.54 \mathrm{kWh} / \mathrm{t}$;

4. Based on the ore characteristic parameters derived from the standard drop weight and Bond work index tests as well as the size requirements for the final products, the SAG + ball mill process was simulated on the JKSimMet platform to determine the required sizes of the mills and the driving power, e.g., $\Phi 10.06 \mathrm{~m} \times 5.03 \mathrm{~m}$ for the SAG mill, $\Phi 5.03 \mathrm{~m} \times 8.23 \mathrm{~m}$ for the ball mill, and the power dissipation of the SAG-ball mill process was 11,088 $(7321+3767) \mathrm{kW}$, while the total specific energy consumption was $17.46(11.53+5.93) \mathrm{kWh} / \mathrm{t}$;

5. Estimates based on the SMC and Bond ball work indices as well as the Morrell model indicated that the specific energy consumption of "jaw crusher + HPGR mill + ball mill" option was lower than the "jaw crusher + ball mill" option, with the "SAG mill + ball mill" option having the highest energy consumption.

Acknowledgments: The authors would like to thank the support from Julius Kruttschnitt Mineral Research Centre (JKMRC) and Beijing General Research Institute of Mining \& Metallurgy (BGRIMM).

Author Contributions: Guangquan Liang designed the experiment and collected all the data under the supervision of Dezhou Wei. Xinyang $\mathrm{Xu}$, and Xiwen Xia were involved in the data analysis process. Yubiao Li reviewed, edited, and added in data interpretation in the manuscript. All the authors discussed the results and approved the manuscript.

Conflicts of Interest: The authors declare no conflict of interest. 


\section{References}

1. Benzer, H.; Ergün, L.; Öner, M.; Lynch, A.J. Simulation of open circuit clinker grinding. Miner. Eng. 2001, 14, 701-710. [CrossRef]

2. Bond, F.C. The third theory of comminution. Min. Eng. Trans. AIME 1952, 193, 484-494.

3. Söderman, P.; Storeng, U.; Samskog, P.O.; Guyot, O.; Broussaud, A. Modelling the new LKAB Kiruna concentrator with USIM PAC ${ }^{\odot}$. Int. J. Miner. Process. 1996, 44-45, 223-235. [CrossRef]

4. Farzanegan, A.; Vahidipour, S.M. Optimization of comminution circuit simulations based on genetic algorithms search method. Miner. Eng. 2009, 22, 719-726. [CrossRef]

5. Irannajad, M.; Farzanegan, A.; Razavian, S.M. Spreadsheet-based simulation of closed ball milling circuits. Miner. Eng. 2006, 19, 1495-1504. [CrossRef]

6. Napier-Munn, T.J.; Lynch, A.J. The modelling and computer simulation of mineral treatment processes-Current status and future trends. Miner. Eng. 1992, 5, 143-167. [CrossRef]

7. Genc, Ö. Optimization of a fully air-swept dry grinding cement raw meal ball mill closed circuit capacity with the aid of simulation. Miner. Eng. 2015, 74, 41-50. [CrossRef]

8. Weller, K.R.; Morrell, S.; Gottlieb, P. Use of grinding and liberation models to simulate tower mill circuit performance in a lead/zinc concentrator to increase flotation recovery. Int. J. Miner. Process. 1996, 44-45, 683-702. [CrossRef]

9. McKee, D.J.; Napier-Munn, T.J. The status of comminution simulation in Australia. Miner. Eng. 1990, 3, 7-21. [CrossRef]

10. Lynch, A.J.; Oner, M.; Benzer, H. Simulation of a closed cement grinding circuit. ZKG Int. 2000, 53, 560-567.

11. Morrell, S. Innovations in comminution modelling and ore characterisation. In Mineral Processing and Extractive Metallurgy: 100 Years of Innovation; Society for Mining, Metallurgy and Exploration (SME): Englewood, CO, USA, 2014.

12. Morrell, S. Predicting the specific energy required for size reduction of relatively coarse feeds in conventional crushers and high pressure grinding rolls. Miner. Eng. 2010, 23, 151-153. [CrossRef]

13. Morrell, S. An alternative energy-size relationship to that proposed by Bond for the design and optimisation of grinding circuits. Int. J. Miner. Process. 2004, 74, 133-141. [CrossRef]

14. Valery, W.; Morrell, S. The development of a dynamic model for autogenous and semi-autogenous grinding. Miner. Eng. 1995, 8, 1285-1297. [CrossRef]

15. Morrell, S. Predicting the overall specific energy requirement of crushing, high pressure grinding roll and tumbling mill circuits. Miner. Eng. 2009, 22, 544-549. [CrossRef]

16. Stark, S.; Perkins, T.; Napier-Munn, T.J. JK drop weight parameters-A statistical analysis of their accuracy and precision, and the effect on SAG mill comminution circuit simulation. In Proceedings of the MetPlant 2008-Metallurgical Plant Design and Operating Strategies, Perth, WA, Australia, 18-19 August 2008; Australasian Institute of Mining and Metallurgy: Carlton, VIC, Australia.

17. Zhou, D.; Zhou, D.-Q.; Liu, J.-Y.; Sun, W.; He, Z. Comminution parameters detection of the ore in Inner Mongolia by drop-weight tests. China Min. Mag. 2015, 24, 339-351.

18. Ozkahraman, H.T. A meaningful expression between bond work index, grindability index and friability value. Miner. Eng. 2005, 18, 1057-1059. [CrossRef]

19. Magdalinovic, N. Procedure for rapid determination of the bond work index. Int. J. Miner. Process. 1989, 27, 125-132. [CrossRef]

20. Xiong, W.; Weng, W.; Zhou, Z. Computer simulation method for the determination of the bond work index. Yu Se Chin Shu/Nonferr. Metals 1984, 36, 28-34. (In Chinese)

21. Xiong, W.; Weng, W.; Zhou, Z. Modelling and simulation of the bond work index test. Zhongnan Kuangye Xueyuan Xuebao 1987, 18, 415-421. (In Chinese)

(C) 2016 by the authors; licensee MDPI, Basel, Switzerland. This article is an open access article distributed under the terms and conditions of the Creative Commons Attribution (CC-BY) license (http:/ / creativecommons.org/licenses/by/4.0/). 